\title{
Factors Influencing Balanced Scorecard Application in Evaluating the Performance of Tourist Firms
}

\author{
Duc Dinh TRUONG ${ }^{1}$, Hoan NGUYEN ${ }^{2}$, Thi Quynh Lien DUONG ${ }^{3}$ \\ Received: March 07, 2020 Revised: March 15, 2020 Accepted: April 03, 2020
}

\begin{abstract}
This study investigates the impact levels of determinants on the Balanced Scorecard application in evaluating the performance of tourism firms in Hanoi. The tourism industry not only promotes economic development, but also contributes to expanding cultural exchanges and improving people's knowledge. However, Vietnam's tourism industry is under fierce competitive pressure, with the participation of foreign enterprises, with large amount of capital, high professionalism and wide network. The rivalry is happening aggressively on many aspects such as products and human resources. Therefore, tourism firms are in urgent needs of having effective methods to evaluate its performance in order to improve business and development efficiency. This study uses data of tourism firms in Hanoi during 2018-2019. The data used for analysis and regression consists of 135 observations. We use Cronbach's Alpha, EFA and regression model to learn the effect of different variables on the Balanced scorecard application in evaluating the performance. The results show that two determinants, including internal factors of tourism firms (IF) and external factors of tourism firms (EF) had positive relationships with the Balanced scorecard application in evaluating the performance. Based on the findings, recommendations are given for improving the Balanced scorecard application in evaluating the performance of tourism firms in Hanoi.
\end{abstract}

Keywords : Balanced Scorecard Application, Performance, Determinants, Tourist Firms

JEL Classification Code: M40, M41, M42, L25, P47

\section{Introduction}

Hanoi, with thousand years of civilization, is considered one of the most abundant and unique tourism resources cities of the country and of the world. The tourism industry in Hanoi has strived to achieve many positive results: during the period of 2016-2018, the number of tourists travelling to Hanoi reached an average growth rate of $10.2 \%$ per year, especially, the growth rate of international tourists coming to

${ }^{1}$ First Author. Lecturer, Faculty of Accounting, University of Labor and Social Affairs, Vietnam. Email: dinhulsa@gmail.com

${ }^{2}$ Corresponding Author, Lecturer, Faculty of Economics, Natural

Resources and Environment, Hanoi University of Natural

Resources and Environment, Vietnam [Postal Address: No. 41A,

Phu Dien Road, Bac Tu Liem District, Hanoi, 100000, Vietnam],

Email: hoannx.nd@gmail.com

${ }^{3}$ Lecturer, Economics Department, Vinh University, Vietnam,

Email: quynhliendhv@gmail.com

(c) Copyright: The Author(s)

This is an Open Access article distributed under the terms of the Creative Commons Attribution Non-Commercial License (http://Creativecommons.org/licenses/by-nc/4.0/) which permits unrestricted noncommercial use, distribution, and reproduction in any medium, provided the original work is properly cited.
Hanoi, which increased up to $22.5 \%$ a year. In 2018, Hanoi welcomed 26.30 million visitors, increasing by $10.4 \%$ and accounting for $27.5 \%$ of total visitors in the whole country. International tourists to Hanoi reached 6.005 million arrivals, accounting for $38.7 \%$ of the number of tourists in the country, reaching $105.2 \%$ of the 2020 target set in Resolution No. 06-NQ/TW. According to the EuroMonitor International Group's list of the top 100 destinations in 2018 on December 5, 2018, Hanoi ranked fourth, compared to other Southeast Asian capitals in welcoming international visitors. (Minh Anh, 2019).

Tourism firms play an important role in the development of the economy. However, awareness of the role and position of the tourism industry has not been enough to contribute to making the tourism industry an important economic sector of the city.

The tourism industry, in general, and tourism firms in Hanoi, in particular, have the following characteristics: cyclical tourism business, continuous hotel business activities in tourism businesses, tourism business is highly direct and synthesized, and tourism business serves a variety of customers. In addition, the tourism industry of Hanoi still 
faces certain difficulties and limitations such as: not exploiting effectively its assets, given the extremely rich and unique tourism potential of the city, fierce competition pressure which will become more intense with the participation of foreign enterprises with strong capital, high professionalism and wide network, etc. Therefore, the operational efficiency of enterprises needs to be assessed accurately to find solutions to promote tourism firms to develop sustainably.

A balance evaluation system developed by Kaplan and Norton (1992), called a Balanced scorecard (BSC), is used to evaluate both financial and non-financial sectors. BSC has measurement function, strategic management function and communication tool function (Kaplan \& Norton, 2001). The BSC system helps businesses assess their performance, orient their vision and business strategies through four basic aspects: financial perspective, customer perspective, internal business process perspective, and learning and growth perspective. However, the application of BSC to evaluate the performance of businesses, in general, and tourism firms in Hanoi, in particular, is not easy due to the complexity of BSC as well as factors affecting the application of BSC.

\section{Literature Review}

There have been many international studies on factors affecting the application of BSC.

Hoque and James (2000) used data from 66 Australian manufacturing companies, to examine the relationship between scale, product life-cycle, organization's market position when using BSC, and effects of BSC implementation on the performance of the organization. The research results show that the use of BSC is affected by the size and product life-cycle. Large companies with new products in their portfolio use BSC more than small companies.

Hendric et al. (2004) conducted a survey of senior executives of 579 Canadian companies, who are closely related to the application and implementation of BSC in organizations. The results show that business strategy, organizational size, and environmental uncertainty do affect BSC's acceptance.

Gica and Moisescu (2007)argue that the factors influencing BSC application are related to the BSC implementation stages in an organization. The research results show that there are ten factors affecting the four successful BSC implementation stages, including: support of senior leaders; proper appreciation of factors that customers, shareholders, employees find valuable; a process of governance with the participation of stakeholders; system design for performing the organization's actual work; scales development at the highest and lowest levels; a communication campaign for BSC in order to lead the focus on the mission and ensure the reliability of the implementation process and the honesty in the report; system arrangement; ensure reliability during implementation and honesty in the report; create transparent and timely information system; and link work results with rewards through the rating system.

Braam and Nijssen (2008) surveyed through questionnaires 40 companies in the Netherlands. Subjects surveyed are mainly accountants, financial directors and managers. The research results indicate that the level of managers' involvement and the power of the financial department play an important role in the acceptance of $\mathrm{BSC}$, in which the degree of centralization and internal communication have a positive impact on the acceptance of $\mathrm{BSC}$ while standardization negatively effects. The remaining two factors - product dynamics and the market - do not affect the acceptance of BSC.

Tanyi (2011) used a questionnaire to survey respondents in some companies in Finland, which had used BSC. The survey subjects are heads of departments of big corporations, presidents, executives and other key personnel in the organizations with decision-making power. The author examines factors that influence managers in their choice in using BSC to explain why some companies use BSC successfully while others do not even though they all use BSC to interpret strategies, to plan, control, feedback and monitor implementation process. The results of the study identify five factors that influence the application of BSC: (i) the current management control system; (ii) manager's ability to acquire new knowledge; (iii) subordinate evaluation method; (iv) recognition of BSC usefulness of managers; and (v) recognition of easy-to-use characteristics of BSC for managers.

Shutibhinyo (2014) suggested that the decisive factor affecting the use of BSC is attitude. The author collected data from 73 survey questionnaires. The research results also showed that the support of leading managers and training process influence the use of BSC through the factor of attitude toward easy-to-use awareness and usefulness of BSC awareness. According to the author, in the process of applying BSC, staff training will influence attitude towards BSC implementation positively and make it easier when applying.

Quesado, Guzmán, and Rodrigues (2014) surveyed 591 publicly-owned organizations and 549 private organizations in Portugal. Data collected were processed with SPSS. The research results identify seven factors affecting the application of BSC in public and private organizations in this country, including: capital ownership form; vertical difference; hierarchy level; standardization, organizational culture; qualifications of managers; and staff.

In the field of tourism, Purnomo, Rahayu, Riani, Suminah, and Udin (2020) found that the tourism development carried out in the Ponggok Village used four approaches: (1) spatial approach as a basis in determining the direction of village development; (2) sectoral approach through increasing the 
Duc Dinh TRUONG, Hoan NGUYEN, Thi Quynh Lien DUONG /

role of the Village Owned Enterprises to build the village economy; (3) human resources to enhance the role of village communities in managing village potentials; and (4) use of information technology to improve service quality, transparency and accountability.

In addition to the studies in the world, there are some related studies in Vietnam, such as Bui (2009), who conducted a research in Ho Chi Minh City. The author uses both qualitative and quantitative research methods. The research results show that there are three factors affecting the application of BSC in small and medium-sized enterprises (SMEs) in Vietnam, which are: usefulness of BSC in that company, easy-to-use characteristic, and general attitude. However, the research model is limited in sample size (only 163 enterprises were analyzed out of more than 300,000 SMEs today, and the scope of research is only implemented in Ho Chi Minh City while SMEs operate in all provinces and cities nationwide).

Tran (2012) used a multivariate regression model to test hypotheses about the influence of factors on the application of BSC. The research results show that there are six factors affecting the application of BSC in enterprises in Vietnam: (i) level of senior leader participation; (ii) level of centralization; (iii) power of the finance department; (iv) standardization; (v) internal communication; and (vi) product-market dynamics. However, the degree of influence of each factor is different. The author also pointed out that senior management in the company plays a crucial role in promoting the innovation process in general and applying BSC in particular.

Tuan (2020) explored the application of Balanced Scorecard in enterprises according to four perspectives of Balanced Scorecard in Vietnamese commercial banks. The author used SPSS 22 to collect and analyze data, based on the results of 109 questionnaires sent to managers and heads of department from Vietnamese commercial banks. Research showed the impact of Balanced Scorecard on the performance of Vietnamese commercial banks.

In addition, a number of studies in Vietnam are also related to research topics such as Do (2011), Huynh (2017), Thuy Linh (2018) and Nguyen, Dang, and Ngo (2019).

\section{Theoretical Background}

\subsection{Contingency Theory}

The contingency theory states that the internal factors and external environmental conditions of each organization are different, so there is no "best" structure for organizations. The application of BSC to assess performance must be consistent with the structure, environment, strategy, technology, scale and culture of the organization (Chenhall, 2006).

This theory relates to the independent variable "internal factors of tourism businesses", specifically the attributes of leaders. In addition, tourism firms in Hanoi have their own characteristics of organizational structure, firm scale, production technology level and business strategy.

\subsection{Stakeholder Theory}

Stakeholder theory refers to organizational governance and business ethics. Stakeholders include groups that are primed to an organization's survival and success (Freeman, 2002). The main groups of stakeholders are: customers, employees, community, suppliers, distributors and shareholders. In addition, other groups and individuals are considered as stakeholders: founders, competitors, trade union representatives, creditors, government, and policy makers (Freeman \& Miles, 2006).

Stakeholder theory is used not only to explain the application of BSC in evaluating performance, but also relates to both internal and external factors of tourism firms that affect the application of BSC in evaluating performance.

\section{Research Methodology}

We collected both primary and secondary data for research purposes. Primary data was collected using questionnaires while secondary data was collected from semi-structured research and interview documents. First, previous literature was reviewed to examine similar studies and gain an overview of the main discussions. The next, we conducted interviews with chief accountants and board of directors from five tourism firms in Hanoi. The authors conducted direct interviews at their workplace and they chose the time to make them feel comfortable. The number of people interviewed in each tourism firm ranges from one to two, depending on the availability of individuals. Totally, eight (8) individuals were interviewed between August and October 2019. The time taken to complete an interview was from 25 to 40 minutes. All interviews were recorded, creating a large data to analyze the factors influencing Balanced scorecard application in evaluating the performance of Tourist firms in Hanoi. All interviewed individuals have experience in the field of research. Respondents are guaranteed the confidentiality of the information they provided.

Next, we designed a questionnaire based on previous research and interview results. Official questionnaires had been distributed to a sample survey included 200 Chief Accountant, General Accountant and Board of Directors who are working at tourism firms in Hanoi in 2019. They interpreted their degree of agreement and disagreement about two factors impacting Balanced scorecard application in evaluating the performance of tourist firms with the use of 5-point Likert scale (from 1 "without effect" to 5 "strongly"). The research model was developed in Figure 1. 


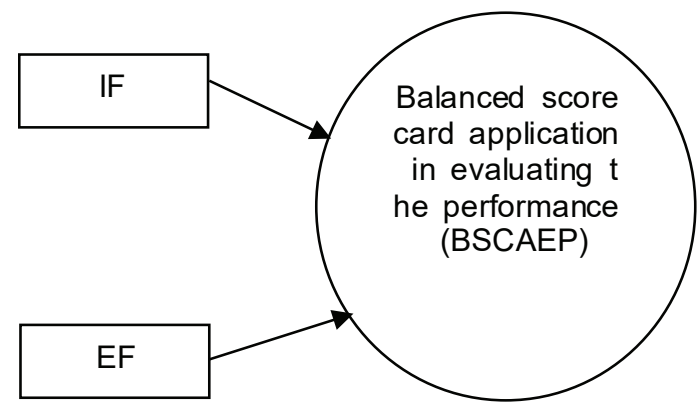

Figure 1: Research model

The survey results collected 150 responses. 15 invalid responses were removed, and 135 valid responses were retained, which met the required sample to reach $95 \%$ in the statistical results. Data analysis was conducted. We entered the responses into SPSS software 22.0. This software allowed us to perform reliability analysis, factor analysis and regression analysis.

Dependent variable: Balanced scorecard application in evaluating the performance (BSCAEP) (Truong, Do, Nguyen, Doan, \& Le, 2020).
Independent variable: The independent variables are described in Table 1.

H1: Internal factors of tourism firms have a positive influence on the balanced scorecard application in evaluating the performance of tourist firms in Hanoi

H2: External factors of tourism firms have a positive influence on the balanced scorecard application in evaluating the performance of tourist firms in Hanoi.

\section{Results}

\subsection{Results of Quality Scale Analysis}

By using scale analysis, we can eliminate inconsistent variables and reduce errors in the research model. Therefore, only variables with total correlation coefficients (Corrected Item - Total Correlation) greater than 0.3 and Cronbach's Alpha coefficients equal or greater than 0.6 are accepted (Hair, Black, Babin, \& Anderson, 2009; Hoang \& Chu, 2008). Analyzing Cronbach's Alpha analysis of determinants has shown their influence on the Balanced scorecard application in

Table 1: Determinants and Its Coding

\begin{tabular}{|c|l|l|}
\hline \multicolumn{2}{|c|}{ Code } & \multicolumn{2}{c|}{ Souriables } \\
\hline Internal factors of Tourism firms (IF) & \multicolumn{1}{|l|}{} \\
\hline IF1 & Business scale & Hoque \& James (2000), Hendric et al. (2004), Tanyi (2011) \\
\hline IF2 & Leadership capacity & $\begin{array}{l}\text { Tanyi (2011), Braam \& Nijssen (2008), Shutibhinyo (2014), } \\
\text { Quesado et al. (2014), Bui (2009), Tran (2012) }\end{array}$ \\
\hline IF3 & $\begin{array}{l}\text { Resources for implementing the evaluation } \\
\text { system }\end{array}$ & Gica and Moisescu (2007), Tanyi (2011), Bui (2009) \\
\hline IF4 & Number of operating years of enterprise & Tanyi (2011) \\
\hline IF5 & Literacy of leadership & $\begin{array}{l}\text { Braam \& Nijssen (2008), Tanyi (2011), Shutibhinyo (2014), } \\
\text { Quesado et al. (2014), Bui (2009), Tran (2012) }\end{array}$ \\
\hline IF6 & Capital structure & Tanyi (2011) \\
\hline IF7 & Information accessibility & Tanyi (2011) \\
\hline IF8 & Managerial experience & $\begin{array}{l}\text { Tanyi (2011), Braam \& Nijssen (2008), Shutibhinyo (2014), } \\
\text { Quesado et al. (2014), Bui (2009), Tran (2012) }\end{array}$ \\
\hline IF9 & Type of business & Tanyi (2011) \\
\hline IF10 & Short-term debt ratio & Do (2011) \\
\hline IF11 & Cash conversion cycle & Huynh (2017) \\
\hline IF12 & Social relationship of enterprises & $\begin{array}{l}\text { Hendric et al. (2004), Braam \& Nijssen (2008), Tanyi } \\
(2011), \text { Bui (2009), Tran (2012) }\end{array}$ \\
\hline External factors of Tourism firms (EF) & \multicolumn{2}{|l}{} \\
\hline EF1 & State policies on tourism attraction & Huynh (2017) \\
\hline EF2 & Government support policies & Results of expert interviews \\
\hline EF3 & Urban landscape in Hanoi & Thuy Linh (2018) \\
\hline EF4 & Tourist sites in Hanoi area & Thuy Linh (2018) \\
\hline EF5 & Restaurants in Hanoi area & Results of expert interviews \\
\hline
\end{tabular}


Duc Dinh TRUONG, Hoan NGUYEN, Thi Quynh Lien DUONG /

evaluating the performance ( 2 determinants with 17 observed variables) and the result is presented in Table 2.

The result shows that all Cronbach's Alpha coefficients of population are above 0.6; all Corrected Item - Total Correlation of observed variables are above 0.3. So, all variables of research model are suitable for next analyses (Hair, Anderson, Tatham, \& Black, 2006).

Table 2: Results of analysis of Determinants Confidence of Scales in the Model

\begin{tabular}{|c|c|c|c|c|}
\hline & $\begin{array}{c}\text { Scale } \\
\text { Mean } \\
\text { if Item } \\
\text { Deleted }\end{array}$ & $\begin{array}{c}\text { Scale } \\
\text { Variance } \\
\text { if Item } \\
\text { Deleted }\end{array}$ & $\begin{array}{c}\text { Corrected } \\
\text { Item-Total } \\
\text { Correlation }\end{array}$ & $\begin{array}{c}\text { Cronbach's } \\
\text { Alpha } \\
\text { if Item } \\
\text { Deleted }\end{array}$ \\
\hline \multicolumn{5}{|c|}{ Internal factors of tourism firms(IF): Cronbach's Alpha: .789 } \\
\hline IF1 & 42.978 & 26.514 & .399 & .777 \\
\hline IF2 & 42.911 & 26.186 & .422 & .775 \\
\hline IF3 & 42.911 & 25.410 & .525 & .763 \\
\hline IF4 & 42.844 & 26.505 & .469 & .770 \\
\hline IF5 & 42.667 & 26.940 & .438 & .773 \\
\hline IF6 & 42.585 & 26.692 & .444 & .772 \\
\hline IF7 & 42.652 & 25.945 & .525 & .764 \\
\hline IF8 & 42.867 & 26.087 & .438 & .773 \\
\hline IF9 & 42.822 & 25.879 & .537 & .763 \\
\hline IF10 & 42.844 & 26.774 & .312 & .788 \\
\hline IF11 & 42.807 & 28.157 & .316 & .784 \\
\hline IF12 & 42.770 & 27.387 & .355 & .781 \\
\hline External factors of tourism firms (EF): Cronbach's Alpha: .792 \\
\hline EF1 & 15.17 & 5.441 & .578 & .751 \\
\hline EF2 & 15.13 & 5.469 & .541 & .765 \\
\hline EF3 & 15.15 & 5.426 & .663 & .724 \\
\hline EF4 & 15.13 & 5.430 & .684 & .718 \\
\hline EF5 & 15.42 & 6.320 & .408 & .780 \\
\hline
\end{tabular}

\subsection{Exploratory Factor Analysis (EFA)}

EFA were conducted and we used the method of extracting coefficients. The results of Component Analysis and Varimax, Analyzes yields 17 attributes for the independent variables (see Table 3).

The results of factor analysis in Table 3 show that $0.5<\mathrm{KMO}=0.766<1$. Bartlett's testimony shows sig. $=0.000$ $<0.05$. It means variables in the whole are interrelated. After implementing the rotation matrix, 2 determinants with factor load factor are greater than 0.5; Eigenvalues are greater than 1 ; the variance explained is $53.411 \%$, which demonstrates that research data analyzing factor discovery is appropriate.
Table 3: KMO and Bartlett's Test

\begin{tabular}{|c|c|c|}
\hline \multicolumn{2}{|c|}{$\begin{array}{c}\text { Kaiser-Meyer-Olkin Measure of Sampling } \\
\text { Adequacy. }\end{array}$} & .766 \\
\hline \multirow{2}{*}{$\begin{array}{c}\text { Bartlett's Test of } \\
\text { Sphericity }\end{array}$} & Approx. Chi-Square & 962.062 \\
\cline { 2 - 3 } & Df & 136 \\
\cline { 2 - 3 } & Sig. & 0.000 \\
\hline
\end{tabular}

Through the quality assurance of the scale and the test of the EFA model, we have identified 2 determinants influencing the balanced scorecard application in evaluating the performance.

\subsection{Regression Model Analysis}

Based on adjusted model after the exploratory factor analysis, we have a multiple regression model as follows:

$\mathrm{BSCAEP}=\alpha+\beta_{1} \mathrm{IF}+\beta_{2} \mathrm{EF}$

Results of Table 4, 5, 6 show that:

Multicollinearity testing: all variance inflation factors (VIF) of independent variables are under 2, so multicollinearity of model is low (Hair et al., 2009; Hoang \& $\mathrm{Chu}, 2008)$. Therefore, this regression model does not have any violation of the CLRM basic assumption.

Durbin-Watson statistics, which is used to test the autocorrelation of residuals, show the model is not violated when using multiple regression method because the DurbinWatson value is in the interval of 1 and 3. In other words, the model indicates no autocorrelation of residuals (Hair et al., 2009; Hoang \& Chu, 2008).

For the Financial Perspective

ANOVA testing result: Level of significant (Sig.) $=0.001$ implies that the multiple regression model is suitable with data. Coefficient of R2 (R Square $)=0.510$, which means $51.0 \%$ of the total variation in the Balanced scorecard's Financial Perspective application in evaluating the performance of tourism firms in Hanoi is explained by the regression model. The research model result indicates that all independent variables, namely, Internal factors of tourism firms (IF) and External factors of tourism firms (EF) are significant (because Sig. $<0.05$ ) to the Balanced scorecard's Financial Perspective application in evaluating the performance. Determinants have influences on the Balanced scorecard's Financial Perspective application in evaluating the performance of Tourist firms in Hanoi are presented in the following standardized regression model:

$\mathrm{BSCAEP}=0.321 \mathrm{IF}+0.217 \mathrm{EF}$

For the Customer Perspective

ANOVA testing result: Level of significant (Sig.) $=0.000$ implies that multiple regression model is suitable with data. 
Coefficient of R2 (R Square) $=0.502$, which means $50.2 \%$ of the total variation in the Balanced scorecard's Customer Perspective application in evaluating the performance of Tourist firms in Hanoi is explained by the regression model. The research model result indicates that all independent variables, namely, Internal factors of tourism firms (IF) and External factors of tourism firms (EF) are significant (because Sig. $<0.05$ ) to the Balanced scorecard's Customer Perspective application in evaluating the performance. Determinants have influences on the Balanced scorecard's Customer Perspective application in evaluating the performance of Tourist firms in Hanoi are presented in the following standardized regression model:

\section{$\mathrm{BSCAEP}=0.116 \mathrm{IF}+0.106 \mathrm{EF}$}

\section{For the Internal Business Process Perspective}

ANOVA testing result: Level of significant (Sig.) $=0.007$ implies that multiple regression model is suitable with data. Coefficient of R2 (R Square) $=0.518$, which means $51.8 \%$ of the total variation in the Balanced scorecard's Internal Business Process Perspective application in evaluating the performance of Tourist firms in Hanoi is explained by the regression model. The research model result indicates that all independent variables, namely, Internal factors of tourism firms (IF) and External factors of tourism firms (EF) are significant (because Sig. $<0.05)$ to the Balanced scorecard's Internal Business Process Perspective application in evaluating the performance. Determinants have influences on the Balanced scorecard's Internal Business Process Perspective application in evaluating the performance of Tourist firms in Hanoi are presented in the following standardized regression model:

\section{$\mathrm{BSCAEP}=0.113 \mathrm{IF}+0.132 \mathrm{EF}$}

For the Learning and Growth Perspective

ANOVA testing result: Level of significant (Sig.) $=0.003$ implies that multiple regression model is suitable with data. Coefficient of R2 (R Square) $=0.515$, which means $51.5 \%$ of the total variation in the Balanced scorecard's Learning and Growth Process Perspective application in evaluating the performance of Tourist firms in Hanoi is explained by the regression model. The research model result indicates that all independent variables, namely, Internal factors of tourism firms (IF) and External factors of tourism firms (EF) are significant (because Sig. $<0.05$ ) to the Balanced scorecard's Learning and Growth Perspective application in evaluating the performance. Determinants have influences on the Balanced scorecard's Learning and Growth Perspective application in evaluating the performance of Tourist firms in Hanoi are presented in the following standardized regression model:

$$
\mathrm{BSCAEP}=0.132 \mathrm{IF}+0.071 \mathrm{EF}
$$

Based on the research results, Hypotheses H1, H2 are accepted.

Table 4: Model Summary ${ }^{\mathrm{b}}$

\begin{tabular}{|c|c|c|c|c|c|}
\hline Model & $\mathbf{R}$ & $\begin{array}{c}\mathbf{R} \\
\text { Square }\end{array}$ & $\begin{array}{c}\text { Adjusted } \\
\mathbf{R} \\
\text { Square }\end{array}$ & $\begin{array}{c}\text { Std. } \\
\text { Error } \\
\text { of the } \\
\text { Estimate }\end{array}$ & $\begin{array}{l}\text { Durbin- } \\
\text { Watson }\end{array}$ \\
\hline \multicolumn{6}{|c|}{ Financial Perspective } \\
\hline 1 & $.711^{\mathrm{a}}$ & .510 & .533 & .35036 & 2.251 \\
\hline \multicolumn{6}{|c|}{ Customer Perspective } \\
\hline 1 & $.717^{\mathrm{a}}$ & .502 & .515 & .62108 & 2.063 \\
\hline \multicolumn{6}{|c|}{ Internal Business Process Perspective } \\
\hline 1 & $.633^{a}$ & .518 & .529 & .59258 & 1.438 \\
\hline \multicolumn{6}{|c|}{ Learning and Growth Perspective } \\
\hline 1 & $.723^{\mathrm{a}}$ & .515 & .500 & .41980 & 1.759 \\
\hline
\end{tabular}

a. Predictors (Constant): EF, IF

b. Dependent Variable: BSCAEP

Table 5: Anova

\begin{tabular}{|c|c|c|c|c|c|}
\hline Model & $\begin{array}{l}\text { Sum of } \\
\text { Squares }\end{array}$ & Df & $\begin{array}{l}\text { Mean } \\
\text { Square }\end{array}$ & $\mathbf{F}$ & Sig. \\
\hline \multicolumn{6}{|c|}{ Financial Perspective } \\
\hline \multirow{3}{*}{$\begin{array}{c}1 \\
\text { Regression } \\
\text { Residual } \\
\text { Total } \\
\end{array}$} & 11.739 & 2 & 10.869 & 17.082 & $.001^{\mathrm{b}}$ \\
\hline & 16.203 & 132 & .123 & & \\
\hline & 27.942 & 134 & & & \\
\hline \multicolumn{6}{|c|}{ Customer Perspective } \\
\hline \multirow{3}{*}{$\begin{array}{c}1 \\
\text { Regression } \\
\text { Residual } \\
\text { Total }\end{array}$} & 20.015 & 2 & 5.008 & 9.020 & $.000^{\mathrm{b}}$ \\
\hline & 50.918 & 132 & .386 & & \\
\hline & 70.933 & 134 & & & \\
\hline \multicolumn{6}{|c|}{ Internal Business Process Perspective } \\
\hline \multirow{3}{*}{\begin{tabular}{|c|}
1 \\
Regression \\
Residual \\
Total \\
\end{tabular}} & 20.838 & 2 & 10.419 & 11.193 & $.007^{b}$ \\
\hline & 46.351 & 132 & .351 & & \\
\hline & 67.189 & 134 & & & \\
\hline \multicolumn{6}{|c|}{ Learning and Growth Perspective } \\
\hline \multirow{3}{*}{$\begin{array}{c}1 \\
\text { Regression } \\
\text { Residual } \\
\text { Total }\end{array}$} & 20.359 & 2 & 10.180 & 1.020 & $.003^{b}$ \\
\hline & 23.263 & 132 & .176 & & \\
\hline & 43.622 & 134 & & & \\
\hline
\end{tabular}

a. Predictors (Constant): EF, IF

b. Dependent Variable: BSCAEP 
Duc Dinh TRUONG, Hoan NGUYEN, Thi Quynh Lien DUONG /

Table 6: Coefficients ${ }^{a}$

\begin{tabular}{|c|c|c|c|c|c|c|c|}
\hline \multirow[t]{2}{*}{ Model } & \multicolumn{2}{|c|}{$\begin{array}{c}\text { Unstandardized } \\
\text { Coefficients }\end{array}$} & \multirow{2}{*}{$\begin{array}{c}\begin{array}{c}\text { Standardized } \\
\text { Coefficients }\end{array} \\
\text { Beta }\end{array}$} & \multirow[t]{2}{*}{$\mathbf{T}$} & \multirow[t]{2}{*}{ Sig. } & \multicolumn{2}{|c|}{$\begin{array}{c}\text { Collinearity } \\
\text { Statistics }\end{array}$} \\
\hline & B & Std. & & & & Tolerance & VIF \\
\hline \multicolumn{8}{|c|}{ Financial Perspective } \\
\hline (Constant) & 3.558 & .278 & & 12.782 & .000 & & \\
\hline IF & .254 & .071 & .321 & 3.589 & .000 & .853 & 1.173 \\
\hline EF & .138 & .057 & .217 & 2.424 & .017 & .853 & 1.173 \\
\hline \multicolumn{8}{|c|}{ Customer Perspective } \\
\hline (Constant) & 3.865 & .493 & & 7.832 & .000 & & \\
\hline IF & .121 & .125 & .116 & .167 & .038 & .853 & 1.173 \\
\hline EF & .117 & .101 & .106 & .166 & .029 & .853 & 1.173 \\
\hline \multicolumn{8}{|c|}{ Internal Business Process Perspective } \\
\hline (Constant) & 4.031 & .471 & & 8.563 & .000 & & \\
\hline IF & .103 & .120 & .113 & .028 & .018 & .853 & 1.173 \\
\hline EF & .136 & .096 & .132 & 1.415 & .019 & .853 & 1.173 \\
\hline \multicolumn{8}{|c|}{ Learning and Growth Perspective } \\
\hline (Constant) & 3.311 & .334 & & 9.927 & .000 & & \\
\hline IF & .119 & .085 & .132 & 1.409 & .016 & .853 & 1.173 \\
\hline EF & .052 & .068 & .071 & .758 & .035 & .853 & 1.173 \\
\hline
\end{tabular}

a. Dependent Variable: BSCAEP

\section{Recommendations}

Balanced scorecard is one of the comprehensive solutions to measure and evaluate the operational aspects of an organization, which include performance. Tourism firms in Hanoi and Vietnam have done research, then applied the balanced scorecard. The research results also show that internal factors of tourism firms (IF) and external factors of tourism firms (EF) influence the application of BSC to evaluate the performance in the same direction, but at different levels.

BSC is an accounting method within the scope of management accounting, with very high flexibility, and dependent on the specific characteristics of each type of business. The above research results also show that the application of BSC depends heavily on the management team of tourism businesses. Therefore, in order to apply BSC, the owner needs to ask the management team to apply $\mathrm{BSC}$ more, require the manager to make an annual report related to the system of BSC criteria. The owner can order the manager to explain the changes, improvements, and arising defects. The manager can also set up a reward regime related to the application of BSC.

The State must accompany the business community, which includes tourism businesses, to implement practical solutions to give the highest level of support in terms of information accessibility. First of all, it is necessary to ensure the timely and complete policies and laws on supporting information provision for businesses. After that, it is essential to promote the coordination mechanism between the State and enterprises in providing legal information to create initiative for enterprises. The government should have a support mechanism to provide information to businesses, more specifically focusing on improving the current legal support services. In addition to the forms of direct counseling, the State can consider building an online counseling model. The State needs to continue simplifying procedures of providing information to businesses.

Building social relationships is extremely important to enterprises to do business. No matter how talented a leader is, no one will hear his name and notice it without social relationships. Therefore, tourism firms in Hanoi need to expand social relationships.

The Hanoi Tourism Association needs to further improve its activities as well as its relationships, which will contribute to raising its prestige and enhance the effectiveness of supporting members. The association should be determined to work together with the localities to comprehensively change the perception and qualifications of tourism teams in the Capital so that they are worthy. In addition, the association 
needs to pay more attention to counseling businesses to build business culture and business ethics as they are the key for sustainable development.

\section{References}

Braam, G. J. M., \& Nijssen, E. J. (2008). Exploring the Antecedents of Balanced Scorecard Adoption as a Performance Measurement and Strategic Management System (NiCE Working Paper 08-115). Nijmegen Center for Economics, Nijmegen, The Netherlands. Retrieved October 15, 2019, from https:// repository.ubn.ru.nl/bitstream/handle/2066/74886/74886.pdf.

Bui, T. H. V. (2009). Factors affecting the intention to apply a balanced scorecard to small and medium enterprises in Vietnam (Master thesis). Ho Chi Minh City University of Technology, Ho Chi Minh, Vietnam.

Chenhall, R. H. (2006). Theorizing contingencies in management control systems research. Handbook of Management Accounting Research, 1, 163-205. https://doi.org/10.1016/ S1751-3243(06)01006-6.

Do, D. T. N. (2011). Financial factors affecting business performance of construction enterprises listed on Vietnam's stock exchange(Master thesis). University of Economics Ho Chi Minh City, Ho Chi Minh, Vietnam.

Freeman, R. E. (2002). Stakeholder Theory of the Modern Corporation. In T. Donaldson \& P. Werhane (Eds.), Ethical Issues in Business: A Philosophical Approach (7th ed., pp. 3848). Englewood Cliffs, N: Prentice Hall.

Friedman, A. L., \& Miles, S. (2006). Stakeholders: Theory and Practice. New York, NY: Oxford University Press.

Gica, O. D., \& Moisescu, O. L. (2007). How to build a successful balanced scorecard. Management and Marketing Journal, 5(1), 140-146.

Hair, J. F., Anderson, R. E., Tatham, R. L., \& Black, W. C. (2006). Multivariate data analysis. Upper Saddle River, NJ: PrenticeHall International.

Hair, J. F., Black, W. C., Babin, B. J., \& Anderson, R. E. (2009). Multivariate Data Analysis (7th ed.). Upper Saddle River, NJ: Prentice Hall International.

Hendricks, K.B., Wiedman, C. I., Menor, L., \& Menor, L. (2004). The Balanced Scorecard to adopt or not to adopt. Ivey Business Journal Online.

Retrieved November 20, 2019, from https://iveybusinessjournal. $\mathrm{com} /$ publication/the-balanced-scorecard-to-adopt-or-not-toadopt.

Hoang, T., \& Chu, N. M. N. (2008). Analysis of research data with SPSS. Hanoi, Vietnam: Hong Duc Publishing House.

Hoque, Z., \& James, W. (2000). Linking balanced scorecard measures to size and market factors: impact on organizational performance. Journal of Management Accounting Research, 12 (1), 1-17. https://doi.org/10.2308/jmar.2000.12.1.1.
Kaplan, R. S., \& Norton, D. P. (1992). The Balanced Scorecard - measures that drive performance. Harvard Business Review, 70(1), 71-79.

Kaplan, R. S., \& Norton, D. P. (2001). Transforming balanced scorecard from performance measurement to strategic management: Part I. Accounting Horizons, 15(1), 87-104.

Huynh, T. N. (2017). Factors affecting business performance of private enterprises in CanTho CanTho City. Journal of economics and development (Vietnam), 235, 95-104.

Minh, A. (2019). Tourism growth contributes to the development of Hanoi Capital. Retrieved June 23, 2019, from http://thanglong. chinhphu.vn/tang-truong-du-lich-dong-gop-cho-phat-trienthu-do-ha-noi.

Nguyen, H. M., Dang, L. A. T., \& Ngo, T. T. (2019). The Effect of Local Foods on Tourists' Recommendations and Revisit Intentions: The Case in Ho Chi Minh City. Vietnam. Journal of Asian Finance, Economics and Business, 6(3), 215-223. https:// doi.org/10.13106/jafeb.2019.vol6.no3.215

Purnomo, S., Rahayu, E. S., Riani, A. L., Suminah, S., \& Udin, U. (2020). Empowerment Model for Sustainable Tourism Village in an Emerging Country. Journal of Asian Finance, Economics and Business, 7(2), 261-270. https://doi.org/10.13106/ jafeb.2020.vol7.no2.261

Quesado, P. R., Guzmán, A. B., \& Rodrigues, L. L. (2014). Determinant Factors of the Implementation of the Balanced Scorecard in Portugal: empirical evidence in public and private organizations. Review of Business Managemnet, 16(51), 199222. DOI: 10.7819/rbgn.v16i51.1335.

Shutibhinyo, W. (2014). Determinants of balanced scorecard usage: indirect correlation through attitudinal factors. Global Journal of Business Reseach, 9(1), 498- 502.

Tanyi, E. (2011). Factor influencing the use of Balanced Scorecard (Thesis Master). Haken School of Economics, Helsinki, Finland.

Thuy, L. (2018). Step by step creating a civilized and modern urban landscape. Retrieved March 20, 2018, from http:// thanglong.chinhphu.vn/tung-buoc-tao-canh-quan-do-thi-vanminh-hien-dai.

Tran, Q.V. (2012). Factors influencing the adoption level of Balanced Scorecard in strategic management of enterprises in Vietnam (Doctoral Thesis). National Economics University, Hanoi, Vietnam.

Truong, D. D., Do, D. D., Nguyen, D. H., Doan, T. Q. A., \& Le, Q. T. (2020). Scale of balanced scorecard application in evaluating the performance of Tourism firms in Hanoi. The International Journal of Business Management and Technology, 4(1), 147-156.

Tuan, T. T. (2020). The Impact of Balanced Scorecard on Performance: The Case of Vietnamese Commercial Banks. Journal of Asian Finance, Economics and Business, 7(1), 7179. https://doi.org/10.13106/jafeb.2020.vol7.no1.71 